\title{
REFLEXE NOUZOVÉHO STAVU V PAMĚŤOVÝCH INSTITUCÍCH A ŠKOLÁCH ZAPOJENÝCH DO PROJEKTU POKUSNÉHO OVĚŘOVÁNÍ „VZDĚLÁVACÍ PROGRAMY PAMĚŤOVÝCH INSTITUCÍ DO ŠKOL 2019/2020"
}

MARTINA HALÍŘOVÁ

Projekt pokusného ověřování „Vzdělávací programy pamětových institucí do škol“ (dále PO) probíhal od školního roku 2017/2018. Vznikl ve spolupráci dvou ministerstev, a to Ministerstva školství, mládeže a tělovýchovy (dále MŠMT) a Ministerstva kultury. Na základě rozhodnutí ministryně školství, mládeže a tělovýchovy Kateřiny Valachové v roce 2017 se Národní pedagogické muzeum a knihovna J. A. Komenského (dále NPMK) stalo koordinátorem tří kol pokusného ověřování. Cílem PO bylo ověřit zájem základních škol o edukační programy pamětových institucí a zjistit vliv muzejní pedagogiky na kvalitu vzdělávání a rozšíření kompetencí žáků. ${ }^{1}$ Projekt vycházel z doporučení mezinárodních organizací (OECD, UNESCO) a ze zavedené praxe některých pamětových institucí, které pomocí muzejní pedagogiky žákům a studentům přibližovaly různá historická období a témata související s pořádanými výstavami prostřednictvím vzdělávacích programů. PO pokračovalo

1 Vyhlášení pokusného ověřování Vzdělávací programy pamětových institucí do škol pro školní rok 2017/2018. In Ministerstvo školství, mládeže a tělovýchovy [online], Praha [cit. 2021-01-21]. Dostupné z www: < https://www.msmt.cz/ vzdelavani/zakladni-vzdelavani/vyhlasenipokusneho-overovani-vzdelavaci-programy-pamet ovych?highlightWords = pam $\%$ C4\%9B\%C5\%A5ov $\%$ C3\%BDch+instituc\%C3\%AD $>$. i ve školním roce 2018/2019. ${ }^{2}$

V následujícím školním roce MŠMT vyhlásilo třetí, poslední běh pokusného ověřování. Poslední rok byl vnímán jako překlenovací období pro možný vznik systémových změn a zapracování této formy vzdělávání do Rámcového vzdělávacího programu. Nově byli do PO zařazeni zástupci nižších stupňů víceletých gymnázií napříč ČR. Celkem se projektu zúčastnilo 84 škol (68 ZŠ a 16 víceletých gymnázií). Zároveň došlo k rozšíření počtu pamětových institucí (dále PI). V prvním roce projektu 2017/2018 bylo zapojeno 10 pamětových institucí se 40 objekty, ve druhém běhu se projekt uskutečnil ve 20 pamětových institucích s 55 objekty a v roce $2019 / 2020$ se zapojilo 22 pamětových institucí se 65 objekty.

Účelem pokusného ověřování bylo ověřit vliv zážitkové pedagogiky na zvýšení kvality výuky společenskovědních a přírodovědných předmětů ve vzdělávacích oblastech Člověk

\footnotetext{
2 TOMEŠKOVÁ, Kateřina. Závěrečná zpráva. Pokusné ověřování „Vzdělávací programy pamětových institucí do škol" - výsledky mapování zájmu základních škol o zážitkovou edukaci, jejich analýza a vyhodnocení [online]. Praha,
2020 [cit. 2021-01-07]. Dostupný z www: <https://www.npmk.cz/sites/default/files/ pokusne-overovani/zaverecna_zprava_po2-def_ msmt_a_npmk_-a_pro_web_mp.pdf $>$.
}

https://doi.org/10.5817/MuB2021-1-5

a jeho svět, Člověk a společnost, Člověk a příroda a Umění a kultura ve vybraných školách, které potvrdily účast na pokusném ověřování, a to prostřednictvím finanční podpory z prostředků státního rozpočtu, která byla určena na pokrytí nákladů přímo souvisejících s návštěvou pamětových institucí v České republice.

Jako koordinátor každoročně NPMK zpracovávalo hlášení od škol a edukačních oddělení pamětových institucí. Na základě hlášení sestavovalo závěrečné zprávy, které byly odevzdávány na MŠMT a zveřejňovány na webových stránkách muzea. ${ }^{3}$ Zároveň NPMK uspořádalo dvě konference určené jak pro edukátory pamětových institucí, tak pro pedagogy základní škol. Projekt i konference potvrdily, že vzdělávání v pamětových institucích rozvíjí v účastnících edukačních programů (žácích) tvưrčí a badatelské postupy a propojuje vzdělávání v širších kontextech. Pamětové instituce hrají významnou roli ve vzdělávání dětí i dospělých.

\footnotetext{
3 Závěrečné zprávy. Pokusné ověřovánî „Vzdělávací programy pamětových institucí do škol“. In Národní pedagogické muzeum a knihovna J. A. Komenského [online]. Praha, 2020 [cit. 2021-01-07]. Dostupné z www: <https://www.npmk.cz/pro-skoly/pokusneoverovani/zaverecne-zpravy >
} 
Cílem příspěvku je reflexe nouzového stavu v pamětových institucích a školách. Na základě odevzdaných hlášení bude porovnána návštěvnost edukačních programů v prvním a druhém pololetí roku 2019/2020. Budou zmíněna opatření vyhlášená vládou v první vlně epidemie. Reflektována bude i prripravenost pamětových institucí a škol na fungování v online prostředí. Zároveň budou v krátkosti představeny výsledky projektu PO. V reflexi jsou využity závěrečné zprávy pokusného ověřování a výsledky šetření České školní inspekce provedené v jarních měsících na 5000 školách a výroční zpráva ČŠI. ${ }^{4}$ Pro informace o dopadech jarního nouzového stavu v pamětových institucích byl využit Věstník Asociace muzeí a galerií. ${ }^{5}$

\section{Opatření v rámci pandemie Covid-19 ve druhém pololetí 2019/2020}

Druhé pololetí školního roku 2019/2020 bylo negativně ovlivněno celosvětovou epidemií nového koronaviru SARS CoV-2 způsobujícího onemocnění Covid-19. V souvislosti s epidemiologickou situací došlo dne 11. března $2020 \mathrm{k}$ uzavření škol a školských zařízení. Usnesením vlády č. 194 ze dne 12. března 2020 vláda v souladu s č. I. 5 a 6 ústavního zákona č. 110/1998 Sb., o bezpečnosti České republiky, vyhlásila pro

\footnotetext{
4 Vzdělávání na dálku v základních a středních školách. Tematická zpráva: květen 2020 [online]. Praha: Česká školní inspekce, 2020 [cit. 2021-01-21]. Dostupné z www: <http://www.csicr.cz/html/2020/ TZ_vzdelavani_na_dalku_ZS_SS/html5/index. html? \&locale $=$ CSY\&pn $=1>$; rovněž viz Kvalita a efektivita vzdělávání a vzdělávací soustavy ve školním roce 2019/2020. Výroční zpráva České školní inspekce [online]. Praha: Česká školní inspekce, 2020 [cit. 2021-01-21]. Dostupné z www: < https://www.csicr.cz/ Csicr/media/Prilohy/PDF_el._publikace/ V\%c3\%bdro\%c4\%8dn\%c3\%ad\%20zpr\%c3\%a1vy/ Vyrocni-zprava-Ceske-skolni-inspekce-2019-2020 zm.pdf $>$.

5 Věstník AMG, 2020, č. 4.
}

území České republiky z důvodu ohrožení zdraví v souvislosti s prokázáním výskytu koronaviru na území České republiky nouzový stav a ve smyslu $\S 5$ písm. a) až e) a § 6 zákona č. $240 / 2000$ Sb., o krizovém řízení a změně některých zákonů (krizový zákon). Z rozhodnutí vlády byl omezen volný pohyb osob v celé České republice. Činnost škol a školských zařízení musela respektovat zákaz volného pohybu, př́kaz pobytu v místě bydliště, omezení kontaktů s jinými osobami na nezbytně nutnou míru. Spolu s tímto omezením vláda vyzvala zaměstnavatele, aby v maximální možné míře u svých zaměstnanců využili práci z domova, aby vyhověli př́ípadným žádostem o dovolenou či placené volno a aby omezili výkon prací, které nejsou významné pro zachování činnosti zaměstnavatele.

$S$ účinností od 20. dubna 2020 bylo předchozí usnesení vlády zrušeno a nahrazeno mimořádným opatřením Ministerstva zdravotnictví (č. j. MZDR 16184/2020-1/MIN/ KAN) ze dne 15. dubna 2020. $\mathrm{V}$ reakci na rozsudek Městského soudu v Praze bylo mimořádné opatření zrušeno a nahrazeno usnesením vlády č. 198/2020 Sb. s účinností od 24. dubna 2020 do 27. dubna 2020 a usnesením vlády č. 197/2020 Sb. s účinností od 27. dubna $2020 .^{6}$

Kvưli opatření nenavštěvovalo školy přibližně 1,7 milionu žáků a studentů, $\mathrm{z}$ toho bylo nejvíce žáků základních škol, kterých je přibližně 953 tisíc. ${ }^{7}$ Školy mohly

\footnotetext{
6 Všechna opatření rozdělena dle segmentů kultura, školství atd. Aktuální opatření. In Covid portál [online]. [cit. 2021-01-22]. Dostupná z www: <https://covid.gov.cz/opatreni>.

7 Statistické údaje převzaty z Uzavření českých škol 2020 v souvislosti s pandemií covidu-19. In Wikipedie [online]. [cit. 2021-01-07]. Dostupné z www: <https://cs.wikipedia.org/wiki/Uzav\%C 5\%99en\%C3\%AD_\%C4\%8Desk\%C3\%BDch_\%C5\% A1kol_2020>.
}

zadávat úkoly elektronicky a výuka $\mathrm{v}$ omezeném režimu pokračovala distanční formou, přičemž žáci a studenti měli povinnost zadané úkoly plnit a vyučující je klasifikovali.

Od poloviny dubna docházelo $\mathrm{k}$ postupnému rozvolňování opatření. V květnu byl stanoven harmonogram uvolnění škol a školských zařízení. K 11. květnu se do škol vrátili žáci devátých tříd, a to výhradně pro účely přípravy na přijímací zkoušky na SŠ. Docházka u výše uvedených nebyla povinná, musela probíhat ve skupinách v maximálním počtu patnácti osob. Od 25. května byla možná osobní přítomnost žáků prvních stupňủ základních škol na vzdělávacích aktivitách formou školních skupin. Účast žáků nebyla povinná. $\mathrm{V}$ rámci ochrany rizikových skupin pedagogických i nepedagogických pracovníků, a stejně tak žáků a jejich rodinných příslušníků nadále pokračovala distanční výuka. Od 8. do 30. června 2020 byla umožněna realizace občasných vzdělávacích a socializačních aktivit pro žáky druhých stupňů základních škol a pro žáky stř̌edních a vyšších odborných škol mimo závěrečné ročníky. Jednalo se o možnost pro školy, přičemž záleželo na konkrétních personálních, materiálních a prostorových podmínkách každé školy, zda této možnosti využije, $v$ jakém rozsahu a jakým způsobem. Nešlo tedy o fungování v obdobném režimu, jako tomu bylo u prvních stupňů základních škol, ale spíše o eventualitu konání konzultací či třridnických hodin. Účast žáků byla dobrovolná.

V souvislosti s nouzovým stavem byly uzavřeny všechny pamětové instituce. K otevření muzeí a galerií došlo dne 11. května 2020, hrady a zámky ve správě Národního památkového ústavu byly otevřeny pro veřejnost od 25 . května. Školská 
zařízení a pamětové instituce musely dodržovat hygienická nařízení zabraňující šíření koronaviru. Ve vnitřních prostorech museli návštěvníci nosit roušky. Nesmělo docházet k shlukování velkého počtu osob. Bylo nařízeno dodržování rozestupů 2 metry s výjimkou blízkých osob a musela být zajištěna možnost dezinfekce rukou. Zároveň v objektech probíhala zvýšená dezinfekce ploch a povrchů. $Z$ uvedených důvodů nebyl možný pobyt větší skupiny žáků v pamětových institucích.

\section{Školy versus první vlna epidemie}

Školy ani rodiče nebyli na distanční výuku připraveni. Vybavenost škol i domácností výpočetní technikou se lišila. Velmi dobře byly na situaci připraveny školy, kde se jejich ředitelé již dříve systematicky věnovali zajištění digitálních technologií. ${ }^{8}$ Rovněž bylo zjištěno, že výuka informačních a telekomunikačních technologií byla před vypuknutím pandemie vedena pouze ze 41,3 \% aprobovanými pedagogy, což se projevilo v nižší míře digitální gramotnosti některých žáků a v jejich nedostatečných dovednostech pro zapojení do on-line výuky. ${ }^{9} \mathrm{~V}$ případě dalšího vzdělávání učitelů bylo opomíjeno vzdělávání v oblasti informačních a komunikačních technologií (účastnilo se ho pouze 16,2 \% učitelů). Toto se negativně projevilo ve druhém pololetí školního roku, kdy se ukázaly nízké kompetence mnoha učitelů pro práci s digitálními technologiemi. ${ }^{10}$

\footnotetext{
8 Kvalita a efektivita vzdělávání a vzdělávací soustavy ve školním roce 2019/2020. Výroční zpráva České školní inspekce [online]. Praha: Česká školní inspekce, 2020, s. 52 [cit. 2021-01-21]. Dostupné z www: <https://www.csicr.cz/ Csicr/media/Prilohy/PDF_el._publikace/ V\%c3\%bdro\%c4\%8dn\%c3\%ad\%20zpr\%c3\%a1vy/ Vyrocni-zprava-Ceske-skolni-inspekce-2019-2020 zm.pdf $>$.

9 Tamtéž, s. 56

10 Tamtéž, s. 57-58.
}

Kvůli absenci počítačů a internetu $\mathrm{v}$ některých rodinách byly školy nuceny hledat i jiná řešení vzdělávání na dálku. Řada neziskových organizací začala sociálně znevýhodněným rodinám zprostř̀edkovávat zapůjčení výpočetní techniky zdarma. ${ }^{11}$ Do pořizování se zapojily obce i kraje. Podle šetření školní inspekce se do online výuky zapojilo zhruba 80 \% dětí ze základních a středních škol. S 9500 žáky základních a středních se nepodařilo navázat komunikaci. Nejsložitější situace nastala $\mathrm{v}$ regionech s nízkým socioekonomickým statusem. ${ }^{12}$

Využívání digitálních technologií vedlo k jiné organizaci práce. Někteří vyučující byli nuceni učit se ovládat techniku v běhu. Příprava výuky se stala náročnější vzhledem k promýšlení jejího obsahu. Velmi významnou se stala zpětná vazba od žáků. ${ }^{13}$ Šetření ukázalo, že zásadní pro kvalitu vzdělávání je kultura školy spojená s kvalitou vedení. ${ }^{14}$ Řada rodičů si stěžovala na přetěžování dětí úkoly. Kvalita on-line výuky souvisela s kvalitou vyučujícího a jeho empatií. V jarní distanční výuce převládaly pasivní činnosti (sledování) nebo samostatné činnosti (nastudování, samostatné vypracování). Učitelé realizovali distanční výuku ve stejném rozsahu jako v běžném rozvrhu při prezenčním vzdělávání. Nereflektovali jarní doporučení Ministerstva školství, mládeže a tělovýchovy, České školní inspekce i dalších institucí věnovat se primárně opakování a procvičování a snažili se probrat s žáky na dálku

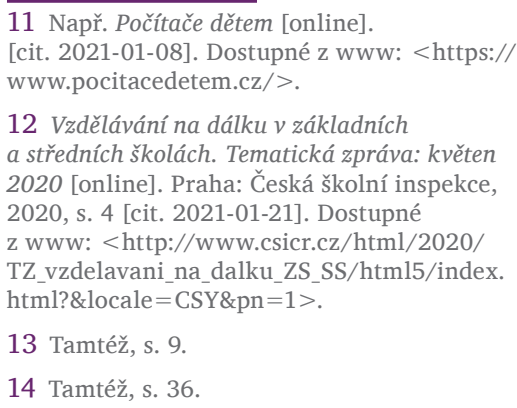

veškerý stanovený vzdělávací obsah. ${ }^{15}$ Během distanční výuky byly děti odkázány na vybavení a podmínky svého domácího prostředí, které není rovnocenné, což významně zvýšilo nerovnosti v přístupu ke vzdělávání. ${ }^{16}$

Při krátkém podzimním návratu dětí do škol (školní rok 2020/2021) se ukázal negativní dopad on-line vzdělávání, starší i mladší žáci během jarní vlny ztratili učební návyky. Řada žáků měla značné mezery v učivu. ${ }^{17}$

\section{Dopad první vlny na pamětové instituce zapojených do pokusného ověřování}

Ve školním roce $2019 / 2020$ bylo do PO3 zapojeno 22 pamětových institucí se 65 objekty. Všechny zapojené instituce uzavřely spolu s nouzovým stavem své brány jak návštěvníkům, tak školním skupinám. K otevření muzeí a galerií došlo dne 11. května 2020, hrady a zámky ve správě NPÚ byly otevřeny pro veřejnost od 25. května. Zatímco v prvním pololetí realizovaly projekt všechny školy (až na jednu, která odstoupila), ve druhém pololetí ho nerealizovalo celkem 64 zapojených škol $(76,19 \%)$ a realizovalo ho jen 20 škol (23,81 \%). Toto se promítlo i na počtu odučených tříd a počtu realizovaných edukačních programů.

\footnotetext{
15 Zkušenosti žáků a učitelů základních škol s distanční výukou ve 2. pololetí školního roku 2019/2020. Tematická zpráva [online]. Praha: Česká školní inspekce, 2020 [cit. 21-01-21]. Dostupné z www: <https://tarantula.ruk.cuni.cz/ AKTUALITY-11135-version1-tz_zkusenosti_zaku_a ucitelu_zs_s_distancni_vyukou_2_pol_2019_2020. pdf $>$.

16 ČERMÁKOVÁ, Barbora, Štěpán KMENT a Karel GARGULÁK. Dopady uzavření škol kvůli pandemii koronaviru: logický model [online]. Praha: EDUin, o. p. s., 2020 [cit. 21-01-21]. Dostupný z www: < https://www.eduin.cz/wpcontent/uploads/2020/08/Dopady_uzavreni_skol pandemie_koronaviru.pdf $>$.

17 SEĎOVÁ, Stáňa. Na jaře online výuka bez 270 tisíc dětí. In Novinky.cz [online].

1. 10. 2020 [cit. 2021-01-14]. Dostupné z www: $<$ https://www.novinky.cz/domaci/clanek/najare-online-vyuka-bez-270-tisic-deti-40337680>
} 


\begin{tabular}{|c|c|c|c|c|c|}
\hline \multirow{2}{*}{ Pamětová instituce } & \multicolumn{2}{|c|}{ Počet tříd } & \multicolumn{2}{|c|}{$\begin{array}{l}\text { Počet edukačních } \\
\text { programů }\end{array}$} & \multirow{2}{*}{$\begin{array}{l}\text { Počet } \\
\text { objekti̊ }\end{array}$} \\
\hline & 1. pololetí & 2. pololetí & 1. pololetí & 2. pololetí & \\
\hline NPMK & 25 & 4 & 46 & 4 & 2 \\
\hline MZM & 129 & 6 & 22 & 2 & 9 \\
\hline NZM & 66 & 6 & 66 & 6 & 3 \\
\hline SZM & 29 & 4 & 29 & 4 & 3 \\
\hline Památník Lidice & 147 & 6 & 52 & 6 & 1 \\
\hline Husitské muzeum v Táboře & 82 & 2 & 82 & 2 & 2 \\
\hline $\begin{array}{l}\text { NM - Náprstkovo muzeum asijských, } \\
\text { afrických a amerických kultur }\end{array}$ & 21 & 8 & 21 & 8 & 2 \\
\hline NM - ČMH & 50 & 36 & 50 & 36 & 1 \\
\hline $\mathrm{NM}-\mathrm{HB}$ a $\mathrm{NB}^{18}$ & 675 & 62 & 369 & 62 & 2 \\
\hline Muzeum umění Olomouc & 18 & 0 & 18 & 0 & 2 \\
\hline NPÚ & 127 & 0 & 127 & 0 & 9 \\
\hline Národní ústav lidové kultury & 25 & 0 & 21 & 0 & 2 \\
\hline NTM Praha & 54 & 3 & 52 & 5 & 3 \\
\hline NTM Brno & 78 & 1 & 83 & 1 & 1 \\
\hline $\begin{array}{l}\text { Národní muzeum v přírodě - } \\
\text { Muzeum v přírodě Vysočina }\end{array}$ & 27 & 0 & 25 & 0 & 1 \\
\hline Celkem & 1553 & 138 & 1063 & 136 & 43 \\
\hline
\end{tabular}

Tab. 1: Počet odučených tříd a realizovaných edukačních programů v rámci PO.

Edukátoři v pamětových institucích, kde dotazník vyplnili, odučili za obě pololetí celkem 1691 tříd v 1199 edukačních programech. Porovnáme-li první a druhé pololetí, je zřetelný velký propad v počtu tříd a edukací způsobený uzavřením škol a pamětových institucí. Většina zrealizovaných edukačních programů proběhla $\mathrm{v}$ měsících únor-březen a $\mathrm{v}$ červnu. $\mathrm{V}$ některých pamětových institucích Muzeum umění Olomouc, Národní památkový ústav, Národní ústav lidové kultury a Národní muzeum v přírodě neproběhly žádné edukace podpořené $\mathrm{z}$ dotace $\mathrm{PO}$. Většina zmíněných institucí má sezónní otevírací dobu, kromě Muzea umění Olomouc. Nevýhodou tohoto muzea bylo, že žádná z podpořených škol nepocházela z Olomouce.

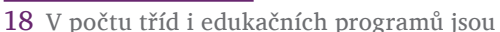
zahrnuty všechny uskutečněné edukace včetně edukací podpořených z PO.
Pamětové instituce zapojené do pokusného ověřování (a nejen ony) reagovaly na nucené uzavření přechodem do on-line prostředí a vytvářely on-line výukové programy, přednášky a hry. Tvořily i tematicky zaměřené pracovní listy s workshopy. ${ }^{19}$ Všechny online aktivity byly na rozdíl od běžných edukačních programů přistupné zdarma. Pamětové instituce a jejich zaměstnanci prokázali schopnost rychle reagovat a přizpůsobit se situaci. Edukační oddělení připravila řadu zajímavých aktivit, které předpokládaly zapojení dětí a rodičů či školních tříd.

Vzhledem k omezení provozu a poklesu počtu jak běžných návštěvníků, tak školních skupin byla zasažena ekonomika institucí.

19 POTU゚ČKOVÁ JURÁŠOVÁ, Vendula. Online aktivity muzeí. Věstník AMG, 2020, č. 4, s. 8-9.
Výrazně poklesly př́ijmy ze vstupného a služeb, na druhou stranu vzrostly náklady na ochranné pomůcky a dezinfekci a na zajištění opětovného návštěvnického provozu. ${ }^{20}$

\section{Porovnání uplynulých let PO}

MŠMT vyčlenilo na projekt PO celkem 55982500 Kč. Každá škola obdržela na školní pololetí stejnou výši dotace, a to 122500 Kč/ škola/pololetí. Školy z obdržených finančních prostředků financovaly výjezdy do zapojených pamětových institucí.

\begin{tabular}{|l|c|c|}
\hline & 1. pololetí & 2. pololetí \\
\hline PO1 & 601 & 562 \\
\hline PO2 & 621 & 476 \\
\hline PO3 & 543 & 31 \\
\hline Celkem & 1765 & 1069 \\
\hline
\end{tabular}

Tab. 2: Počet navštívených pamětových institucí.

V letech 2017-2020 školy v rámci školního roku navštívily celkem 2834 pamětových institucí. Při porovnání průběhu $\mathrm{PO}$ zjistíme, že PO3 je oproti PO1 a PO2 slabší a školy v prvním pololetí navštívily menší počet pamětových institucí než v předchozích letech, a to o $12,56 \%$ méně než při PO2 a o 9,65 \% méně než v rámci PO1. Podle informací ze škol přišly finanční prostředky na účty pozdě a řada škol neměla možnost předfinancovat výjezdy. Zároveň školy, které se účastnily předchozích pokusných ověřování, si stěžovaly na nedostatečné množství zapojených pamětových institucí a na to, že pamětové instituce neobměňují edukační programy. Na druhou stranu školy v rámci PO3 zorganizovaly více vícedenních výjezdů než

20 KUCHYŇKA, Zdeněk. Zamyšlení nad ekonomickými dopady. Věstník AMG, 2020, č. 4, s. 5. 


\begin{tabular}{|l|c|c|c|c|}
\hline \multirow{2}{*}{} & \multicolumn{2}{|c|}{ Jednodenní výjezdy } & \multicolumn{2}{c|}{ Několikadenní výjezdy } \\
\cline { 2 - 5 } & 1. pololetí & 2. pololetí & 1. pololetí & 2. pololetí \\
\hline PO1 & 562 & 493 & 39 & 69 \\
\hline PO2 & 582 & 395 & 39 & 81 \\
\hline PO3 & 560 & 40 & 85 & 0 \\
\hline Celkem & 1704 & 928 & 163 & 150 \\
\hline
\end{tabular}

Tab. 3: Počet jednodenních a vícedenních výjezdů.

v předchozích letech (viz Tab. 3). Časová náročnost přesunů mezi sídly pamětových institucí vedla ke snížení počtu návštěv. V rámci celého PO bylo možno sledovat všeobecný trend, že ve druhém pololetí školy realizovaly méně výjezdů než v prvním pololetí. Nutnost čerpání peněz vedlo školy $\mathrm{k}$ organizaci výjezdů i $\mathrm{v}$ méně klimaticky příznivých měsících a ke snaze více navázat návštěvu pamětové instituce na výuku. Pozitivem bylo umožnění realizace i vícedenních výjezdů.

Ve druhém roce realizace projektu (PO2) došlo k nárůstu podzimních jednodenních exkurzí, počet vícedenních výjezdů zůstal nezměněn. Ve druhém pololetí PO2 lze sledovat nárůst vícedenních výjezdů. $\mathrm{V}$ rámci PO3 došlo v prvním pololetí k nárůstu počtu vícedenních výjezdů. Bylo jich uskutečněno 85 , což je o $54 \%$ více než $\mathrm{v}$ rámci $\mathrm{PO} 1$ a $\mathrm{PO} 2$. Kvůli nárůstu vícedenních výletů klesl počet jednodenních exkurzí na 560, tento pokles není vysoký, činí pouze $3,78 \%$ oproti PO2. Ve druhém pololetí školy realizovaly 40 jednodenních výjezdů, které se uskutečnily v měsících únor-březen a červen. Vícedenní výjezd nebyl realizován.

Průměrná částka vydaná na žáka dosáhla v prvním pololetí 2019/2020 462,70 Kč. V porovnání $s$ předchozími ročníky PO se jedná o značný nárůst, během $\mathrm{PO} 1$ se jednalo o 210 Kč, v PO2 o 208 Kč na jednoho žáka. Vyšší průměrnou částku v rámci PO3 lze odůvodnit pořádáním vícedenních výjezdo̊.

Závěrečné zprávy obsahují informace o počtu žáků, kteří navštívili pamětové instituce a jejich edukační programy, můžeme tak v průběhu tř́i let porovnat jejich počty.

Porovnáme-li jednotlivá pokusná ověřování, zjistíme, že v prvním pololetí PO3 došlo $\mathrm{k}$ poklesu počtu zúčastněných žáků, a to o 43,93 \% než při PO2. Pokles lze vysvětlit realizací většího množství vícedenních výjezdů, než tomu bylo v předchozích letech. Sečtemeli první i druhé pololetí všech proběhlých $\mathrm{PO}$, zjistíme, že díky dotaci se edukačních programů zúčastnilo 162057 studujících.

$\mathrm{V}$ průběhu $\mathrm{PO} 1$ bylo průměrně vyčerpáno 83,94 \% dotace, vratka činila 16,06 \%. Během PO2 bylo vyčerpáno $84 \%$ přidělených prostředků. Vratka činila $16 \%$. V prvním pololetí PO3 školy vyčerpaly $87 \%$, vracely $13 \%$ dotace. Ve druhém pololetí bylo vráceno $96 \%$ dotace $\mathrm{z}$ důvodu protiepidemických opatření. Za obě pololetí vratka dosáhla $54,54 \%$. Školy v období od poloviny března do května 2020 nemohly vyjíždět do pamětových institucí a pamětové instituce nemohly školní skupiny přijímat, po rozvolnění řada škol se snažila sanovat výuku a ověřit znalosti žáků získané prostřednictvím distanční výuky, proto 64 škol ve druhém pololetí roku 2019/2020 neuskutečnilo

\begin{tabular}{|l|c|c|}
\hline & 1. pololetí & 2. pololetí \\
\hline PO1 & 31343 & 37772 \\
\hline PO2 & 34735 & 37714 \\
\hline PO3 & 19436 & 1057 \\
\hline Celkem & 85514 & 76543 \\
\hline
\end{tabular}

Tab. 4: Porovnání počtu zúčastněných žáků.

žádný výjezd, alespoň jeden výjezd uskutečnilo 20 škol, přičemž většina výjezdů proběhla $\mathrm{v}$ období před vyhlášením nouzového stavu, několik výjezdu se uskutečnilo $\mathrm{v}$ červnu. Školy v Jihočeském, Libereckém, Pardubickém, Zlínském a Olomouckém kraji ve druhém pololetí nerealizovaly $\mathrm{z}$ důvodu epidemie žádný výjezd a čerpaly pouze částku určenou pro pověřenou osobu. Nejvíce pamětových institucí ve druhém pololetí (11) navštívily školy ze Středočeského kraje, nejaktivnější byla škola z Kladna. Nejlépe čerpala prostředky škola z Karlovarského kraje, která vyjela $v$ době před uzavřením škol do Prahy. Výše čerpání byla dána vzdáleností školy od cílové destinace.

Pro dopravu do pamětových institucí školy více využívaly objednané soukromé dopravce. Př́íčinou pro upřednostnění objednané autobusové přepravy byla zejména rychlost, snadná dostupnost a časová flexibilita. $S$ řadou těchto smluvních partnerů školy spolupracovaly již dříve, proto byl jim dopravce schopen nabídnout i slevu na jízdném. Pokud školy využily vlaky, motivací byla poloha na trase železnice a slevy pro děti ve vlacích. Pro všechny vyučující byla důležitá dopravní dostupnost a spolehlivost dopravce.

\section{Závěr}

První vlna pandemie

Covid-19 způsobila propad $\mathrm{v}$ př́jimech ze vstupného ve všech pamětových institucích. Má 
sociální a ekonomické dopady na všechny obyvatele. Negativně ovlivnila i PO, kdy došlo k propadu realizovaných návštěv. Školy neměly možnost vyčerpat finanční prostředky vázané na realizaci projektu. Celková vratka dosáhla 54,54 \% dotace. Pamětové instituce i školy byly schopny na situaci rychle reagovat a přejít do online prostředí. Všichni byli situací nuceni získávat nové kompetence v oblasti informačních technologií.

Projekt pokusného ověřování Vzdělávací programy pamětových institucí do škol ukázal, že školy mají zájem o realizaci výjezdů do pamětových institucí a o jimi nabízené edukační programy. Zároveň cílená dotace umožnila výjezd i dětem, které by bez ní nevyjely. Sanovala částečně špatné sociální podmínky, ve kterých žijí. Projekt ukázal, že je nutné vylepšit komunikaci mezi pamětovými institucemi - školou. Školy by neměly nahlížet na pamětové instituce pouze jako na „servisní zařízení.“ Měly by je vnímat jako rovnocenné partnery.

Realizace PO1, PO2, PO3 zdůvodnily nutnost změny školského zákona. Na základě této změny již nebudou návštěvy edukačních programů pamětových institucí realizovány formou administrativně náročného pokusného ověřování. Od 1. ledna 2021 došlo k razantnímu navýšení normativně přidělovaných ONIV (finance pro běžné výdaje) pro školy, čímž budou moci školy, výdaje spojené s návštěvou pamětových institucí, tj. výdaje na dopravu při akcích v rámci vzdělávání podle př́slušného rámcového vzdělávacího programu (dle § 160, odst. 1., písm. c) a d) školského zákona), zajištovat přímo ze svého stanoveného rozpočtu přímých výdajů. ${ }^{21}$

21 Legislativní novinky ve školním roce 2020/2021. In Ministerstvo školství, mládeže a tělovýchovy [online], Praha [cit. 2021-01-07]. Dostupné z www: <https://www.msmt.cz/ legislativni-novinky-ve-skolnim-roce-2020-21?hi
V současnosti je otázkou je, kdy se pamětové instituce i školy budou moci vrátit $\mathrm{k}$ běžnému provozu a zda školy opět budou projevovat zájem o edukační programy.

\section{SEZNAM POUŽITÝCH ZDROJŮ A LITERATURY:}

Aktuální opatření. In Covid portál [online]. [cit. 2021-01-22]. Dostupná z www: $<$ https://covid.gov.cz/opatreni $>$.

ČERMÁKOVÁ, Barbora, Štěpán KMENT a Karel GARGULÁK. Dopady uzavření škol kvůli pandemii koronaviru: logický model [online]. Praha: EDUin, o. p. s., 2020 [cit. 21-01-21]. Dostupný z www: $<$ https://www.eduin.cz/wp-content/ uploads/2020/08/Dopady_uzavreni_ skol_pandemie_koronaviru.pdf $>$.

KUCHYŇKA, Zdeněk. Zamyšlení nad ekonomickými dopady. Věstník $A M G$, 2020, č. 4, s. 5-6.

\section{ISSN 1213-2152.}

Kvalita a efektivita vzdělávání a vzdělávací soustavy ve školním roce 2019/2020. Výroční zpráva České školní inspekce [online]. Praha: Česká školní inspekce, 2020 [cit. 2021-01-21]. Dostupné z www: <https://www.csicr.cz/Csicr/ media/Prilohy/PDF_el._publikace/ V\%c3\%bdro\%c4\%8dn\%c3\%ad\%20 zpr\%c3\%a1vy/Vyrocni-zprava-Ceskeskolni-inspekce-2019-2020_zm.pdf >. ISBN 978-80-88087-43-4.

Legislativní novinky ve školním roce 2020/2021. In Ministerstvo školství, mládeže a tělovýchovy [online], Praha [cit. 2021-01-07]. Dostupné z www: $<$ https://www.msmt.cz/legislativninovinky-ve-skolnim-roce-2020-21?highli ghtWords $=\%$ C5\%A1kolsk $\% \mathrm{C} 3 \% \mathrm{BD}+\mathrm{z} \%$ C3\%A1kon>.

Počítače dětem [online]. [cit. 2021-01-08]. Dostupné z www: <https://www. pocitacedetem.cz/>.

POTƯČKOVÁ JURÁŠOVÁ, Vendula. Online aktivity muzeí. Věstník AMG, 2020, č. 4, s. 8-9. ISSN 1213-2152.

SEĎOVÁ, Stáňa. Na jaře online výuka bez 270 tisíc dětí. In Novinky.cz [online]. 1. 10. 2020 [cit. 2021-01-14]. Dostupné

ghlightWords $=\%$ C5\%A1kolsk $\% \mathrm{C} 3 \% \mathrm{BD}+\mathrm{z} \% \mathrm{C} 3 \%$ A1kon>. z www: <https://www.novinky.cz/ domaci/clanek/na-jare-online-vyukabez-270-tisic-deti-40337680>.

TOMEŠKOVÁ, Kateřina. Závěrečná zpráva. Pokusné ověřování „Vzdělávací programy pamětových institucí do škol“ - výsledky mapování zájmu základních škol o zážitkovou edukaci, jejich analýza a vyhodnocení [online]. Praha, 2020 [cit. 2021-01-07]. Dostupný z www: <https://www.npmk.cz/sites/ default/files/pokusne-overovani/ zaverecna_zprava_po2-def_msmt_a_ npmk_-a_pro_web_mp.pdf $>$.

TOMEŠKOVÁ, Kateřina. Závěrečná zpráva. Pokusné ověřvání „Vzdělávací programy pamětových institucí do škol“ analýza výsledků mapování zájmu základních škol o zážitkovou edukaci a její zhodnocení [online]. Praha, 2019 [cit. 2021-01-07]. Dostupný z www: <https://www.npmk.cz/sites/ default/files/pokusne-overovani/ zaverecna_zprava_po-verze_pro_ver.def. pdf $>$.

Uzavření českých škol 2020 v souvislosti s pandemií covidu-19. In Wikipedie [online]. [cit. 2021-01-07]. Dostupné z www: https://cs.wikipedia.org/wiki/ Uzav\%C5\%99en\%C3\%AD_\%C4\%8Desk \%C3\%BDch_\%C5\%A1kol_2020>.

Věstník AMG, 2020, č. 4. ISSN 1213-2152.

Vzdělávání na dálku $v$ základních a středních školách. Tematická zpráva: květen 2020 [online]. Praha: Česká školní inspekce, 2020 [cit. 2021-01-21]. Dostupné z www: <http://www. csicr.cz/html/2020/TZ_vzdelavani_ na_dalku_ZS_SS/html5/index. html? \&locale $=$ CSY\&pn $=1>$.

Vyhlášení pokusného ověřování Vzdělávací programy pamětových institucí do škol pro školní rok 2017/2018. In Ministerstvo školství, mládeže a tělovýchovy [online], Praha [cit. 2021-01-21] Dostupné z www: $<$ https://www.msmt.cz/vzdelavani/ zakladni-vzdelavani/vyhlasenipokusneho-overovani-vzdelavaciprogramy-pametovych?highlightWords $=p$ am\%C4\%9B\%C5\%A5ov\%C3\%BDch+insti tuc\%C3\%AD>.

Závěrečné zprávy. Pokusné ověřování „Vzdělávací programy pamětových institucí do škol“. In Národní pedagogické muzeum a knihovna J. A. Komenského [online]. Praha, 2020 [cit. 2021-01-07]. 
Dostupné z www: < https://www. npmk.cz/pro-skoly/pokusne-overovani/ zaverecne-zpravy $>$.

Zkušenosti žáků a učitelů základních škol s distanční výukou ve 2. pololetí školního roku 2019/2020 [online].
Tematická zpráva. Praha: Česká školní inspekce, 2020 [cit. 21-01-21]. Dostupné z www: <https://tarantula. ruk.cuni.cz/AKTUALITY-11135-version1tz_zkusenosti_zaku_a_ucitelu_zs_s_ distancni_vyukou_2_pol_2019_2020.pdf >.

\section{MARTINA HALÍŘOVÁ}

Pedagogické muzeum, Národní pedagogické muzeum a knihovna J. A. Komenského, Praha,

Česká republika

halirova@npmk.cz 